\title{
Cytotoxicity and Genotoxicity Evaluation of Organochalcogens in Human Leucocytes: A Comparative Study between Ebselen, Diphenyl Diselenide, and Diphenyl Ditelluride
}

\author{
Diones Caeran Bueno, Daiane Francine Meinerz, \\ Josiane Allebrandt, Emily Pansera Waczuk, Danúbia Bonfanti dos Santos, \\ Douglas Oscar Ceolin Mariano, and João Batista Teixeira Rocha
}

Laboratório de Bioquímica Toxicológica, Departamento de Química, Centro de Ciências Naturais e Exatas, Universidade Federal de Santa Maria, Santa Maria 97105-900, RS, Brazil

Correspondence should be addressed to João Batista Teixeira Rocha; jbtrocha@yahoo.com.br

Received 5 October 2013; Accepted 6 November 2013

Academic Editor: Daiana Avila

Copyright (C) 2013 Diones Caeran Bueno et al. This is an open access article distributed under the Creative Commons Attribution License, which permits unrestricted use, distribution, and reproduction in any medium, provided the original work is properly cited.

\begin{abstract}
Organochalcogens, particularly ebselen, have been used in experimental and clinical trials with borderline efficacy. (PhSe) ${ }_{2}$ and $(\mathrm{PhTe})_{2}$ are the simplest of the diaryl dichalcogenides and share with ebselen pharmacological properties. In view of the concerns with the use of mammals in studies and the great number of new organochalcogens with potential pharmacological properties that have been synthesized, it becomes important to develop screening protocols to select compounds that are worth to be tested in vivo. This study investigated the possible use of isolated human white cells as a preliminary model to test organochalcogen toxicity. Human leucocytes were exposed to $5-50 \mu \mathrm{M}$ of ebselen, $(\mathrm{PhSe})_{2}$, or $(\mathrm{PhTe})_{2}$. All compounds were cytotoxic (Trypan's Blue exclusion) at the highest concentration tested, and Ebselen was the most toxic. Ebselen and ( $\mathrm{PhSe})_{2}$ were genotoxic (Comet Assay) only at $50 \mu \mathrm{M}$, and $(\mathrm{PhTe})_{2}$ at 5-50 $\mu \mathrm{M}$. Here, the acute cytotoxicity did not correspond with in vivo toxicity of the compounds. But the genotoxicity was in the same order of the in vivo toxicity to mice. These results indicate that in vitro genotoxicity in white blood cells should be considered as an early step in the investigation of potential toxicity of organochalcogens.
\end{abstract}

\section{Introduction}

Selenium (Se) is an essential microelement for human and animal nutrition [1]. It is important for selenoprotein synthesis, where it is present as the aminoacid selenocysteine [2] Several selenoenzymes, such as Glutathione Peroxidase (GPx) and Thioredoxin Reductase (TrxR), are important for the cell defense against oxidative stress [3,4]. Taking this role of Se in living beings, many therapeutic trials explored the use of inorganic forms of Se as pharmacological agents [5]. However, inorganic forms of Se, such as selenite and selenate, are poorly absorbed and present many toxic effects at high concentrations [6]. Consequently, the interest in organic forms of selenium, that can be less toxic and better absorbed than Se (IV) and Se (VI), has increased.
Tellurium (Te) is chemically related to Se and can be occasionally found in some proteins in bacteria, yeast, and fungi, but no functional telluroproteins have been found in animal cells [7]. In contrast to Se, Te does not have biological function [8]. However, the literature has demonstrated immunomodulatory, antioxidant, and anticancer properties of various organotellurides $[9,10]$. Organotellurium compounds can also mimic Glutathione Peroxidase activity [11], and, consequently, these compounds can be potential antioxidants, effective against some cell damaging agents [12-14].

Ebselen and Diphenyl Diselenide $\left((\mathrm{PhSe})_{2}\right)$ are two organoselenium compounds that are recognized as promising pharmacological agents presenting antioxidant, anti-inflammatory, neuroprotective, and other beneficial properties [9]. These compounds can exert their pharmacological effects by 
mimicking the native Glutathione Peroxidase enzyme (GPxlike activity) or by being a substrate of TrxR. The selenol intermediate formed after their reduction can reduce the levels of reactive oxygen species (ROS) in the cell and prevent oxidative damage to lipids, proteins, and DNA [15-18]. Diphenyl Ditelluride $\left((\mathrm{PhTe})_{2}\right)$ is an organotellurium compound that also showed antioxidant and other in vitro pharmacological properties [9]. Therefore, the experimental use of organoselenium and -tellurium compounds in different models of human diseases has increased [19-23].

On the other hand, ebselen, $(\mathrm{PhSe})_{2}$, and $(\mathrm{PhTe})_{2}$ can be toxic when administered at high doses. This toxicity is thought to be associated with inhibition of thiol- and/or selenol-containing enzymes, which can increase ROS formation, lipid peroxidation, and DNA damage [24-27].

However, the quantity of new organoselenium and tellurium compounds with pharmacological potential that have been synthesized is increasing rapidly. Consequently, information about the toxicity of new organochalcogens is needed. However, we do not have a simple preliminary test to determine the potential toxicity of a great number of new compounds. This point is critical both in view of the time required to perform assays with vertebrates and the need of ethical adherence to the $3 \mathrm{R}$ principal in the use of experimental animals. Here we compare the toxicity of ebselen (which has been used in different clinical trials), $(\mathrm{PhSe})_{2}$ (which is a very simple and pharmacologically active diselenide), and $(\mathrm{PhTe})_{2}$ (a simple and pharmacologically active ditelluride which is also very toxic in vivo to rodents) in human white blood cells to determine whether these cells could be used to do a preliminary screening of potentially toxic new organochalcogens.

In short, the aim of this study was to define the cytotoxic concentrations of ebselen, $(\mathrm{PhSe})_{2}$, and $(\mathrm{PhTe})_{2}$ in freshly isolated white human blood cells. Therefore, human leucocytes were exposed to compounds, and their potencial cytotoxic and genotoxic effects were measured using Trypan's Blue Exclusion and Comet Assay Tests.

\section{Materials and Methods}

2.1. Chemicals. Ebselen, $(\mathrm{PhSe})_{2},(\mathrm{PhTe})_{2}$, Trypan's Blue, dextran, and tungstosilicic acid were obtained from SigmaAldrich (St. Louis, MO). All the other reagents were obtained from standard chemical suppliers.

2.2. Sample Preparation. Leucocytes were isolated from heparinized venous blood obtained from healthy volunteers. The protocol of study was reviewed and approved by the appropriate institutional review board from Guidelines of the Committee of UFSM (0089.0.243.000-07).

$2 \mathrm{~mL}$ of dextran 5\% (dissolved in Phosphate Buffer Saline $1 \%$ ) was added to $8 \mathrm{~mL}$ of blood. The tube was gently mixed and left to stand at room temperature for $45 \mathrm{~min}$. Afterwards, the supernatant was centrifuged $(480 \times \mathrm{g}, 10 \mathrm{~min})$ and plasma was discarded. The pellet was washed with erythrocyte lysis solution $\left(\mathrm{NH}_{4} \mathrm{Cl} 150 \mathrm{mM}\right.$; $\mathrm{NaHCO}_{3} 10 \mathrm{mM}$; EDTA $\left.1 \mathrm{mM}\right)$ and centrifuged $(480 \times \mathrm{g}, 2 \mathrm{~min})$. The supernatant was discarded and the pellet was washed twice with $1 \mathrm{~mL}$ erythrocyte lysis solution. After the second centrifugation, the pellet was suspended in $2 \mathrm{~mL}$ Hank's buffer solution ( $\mathrm{KCl} 5.4 \mathrm{mM}$; $\mathrm{Na}_{2} \mathrm{HPO}_{4} \quad 0.3 \mathrm{mM} ; \mathrm{KH}_{2} \mathrm{PO}_{4} 0.4 \mathrm{mM} ; \mathrm{NaHCO}_{3} 4.2 \mathrm{mM}$; $\mathrm{MgCl}_{2} \quad 0.5 \mathrm{mM}$; $\mathrm{NaCl} 122.6 \mathrm{mM}$; D-glicose $10 \mathrm{mM}$, Tris$\mathrm{HCl} 10 \mathrm{mM} ; \mathrm{CaCl}_{2} 1.3 \mathrm{mM} ; \mathrm{pH}$ 7.4). The concentration of leucocytes was adjusted to 2000 cells $/ \mu \mathrm{L}$.

2.3. Leucocytes Exposure to Organochalcogens. Leucocytes were exposed to ebselen, $(\mathrm{PhSe})_{2}$, and $(\mathrm{PhTe})_{2}$ at 5,10 , and $50 \mu \mathrm{M}$ or an equal volume of DMSO (final concentration of $0.5 \%$ ) during 3 hours at $37^{\circ} \mathrm{C}$. Positive control group was treated with hydrogen peroxide $\left(\mathrm{H}_{2} \mathrm{O}_{2}\right) 2 \mathrm{mM}$ and sodium azide $1 \mathrm{mM}$.

2.4. Trypan's Blue Exclusion Test. Trypan's Blue exclusion test was performed according to Mischel and Shiingi [28]. After 3 hours of incubation, $50 \mu \mathrm{L}$ of Trypan's Blue $0.4 \%$ was mixed with $50 \mu \mathrm{L}$ of leucocytes and left to stand at room temperature for 5 minutes. Cell viability was determined microscopically (400x magnification) and expressed as number of viable cells divided by the total number of cells multiplied by 100 .

2.5. Comet Assay. Comet Assay was performed according to Collins [29] with some modifications. After three hours of incubation, $15 \mu \mathrm{L}$ of the sample was mixed with $90 \mu \mathrm{L}$ of lowmelting point agarose $0.75 \%$ and placed in a slide precoated with agarose $1 \%$. A coverslip was added and the samples were left to solidify at $4^{\circ} \mathrm{C}$. The coverslips were removed and the slides were placed on a lysis solution $(\mathrm{NaCl} 2.5 \mathrm{M}$; EDTA 100 mM; Tris-HCl 8 mM; Triton X-100 1\%; pH 10-10.5) during 24 hours at $4^{\circ} \mathrm{C}$. Afterwards, the slides were incubated in an electrophoresis solution $(\mathrm{NaOH} 300 \mathrm{mM}$; EDTA $1 \mathrm{mM}$; $\mathrm{pH}$ 13.5) for 20 minutes at $4^{\circ} \mathrm{C}$ and the electrophoresis was performed $(25 \mathrm{~V} ; 300 \mathrm{~mA} ; 7 \mathrm{~W})$ for 20 minutes. All the steps were performed in the dark until this moment. After electrophoresis, the slides were washed in a neutralizing solution (Tris- $\mathrm{HCl} 400 \mathrm{mM}$; pH 7.5) three times, washed with distilled water, and left to dry. The slides were rehydrated and fixed (Trichloroacetic acid 15\%; $\mathrm{ZnSO}_{4} 5 \%$; glycerol 5\%), washed three with distilled water, and left to dry. Afterwards, the rehydrated slides were stained $\left(\mathrm{Na}_{2} \mathrm{CO}_{3} 5 \% ; \mathrm{NH}_{4} \mathrm{NO}_{3} 0.1 \%\right.$; $\mathrm{AgNO}_{3} \quad 0.1 \% ; \mathrm{H}_{4}\left[\mathrm{~W}_{12} \mathrm{SiO}_{40}\right]$ 0.25\%; formaldehyde $0.15 \%$ ). The slides were immersed in acetic acid $1 \%$, washed, and left to dry.

One hundred cells randomly selected were analyzed in each sample according to tail size and intensity in five classes. The damage score for each cell can range between 0 (no damage) and 4 (maximum damage), according to Figure 1. Damage index (DI) was defined as follows: DI $=1 n 1+2 n 2+$ $3 n 3+4 n 4$, where $n 1$ represents the number of cells with damage level $1, n 2$ represents the number of cells with damage level $2, n 3$ represents the number of cells with damage level 3, and $n 4$ represents the number of cells with damage level 4 . At least two different individuals analyzed the slides under blind conditions.

2.6. Statistical Analysis. Statistical analyses were performed using analysis of variance (ANOVA) followed by NewmanKeuls multiple test when appropriate. The results are 

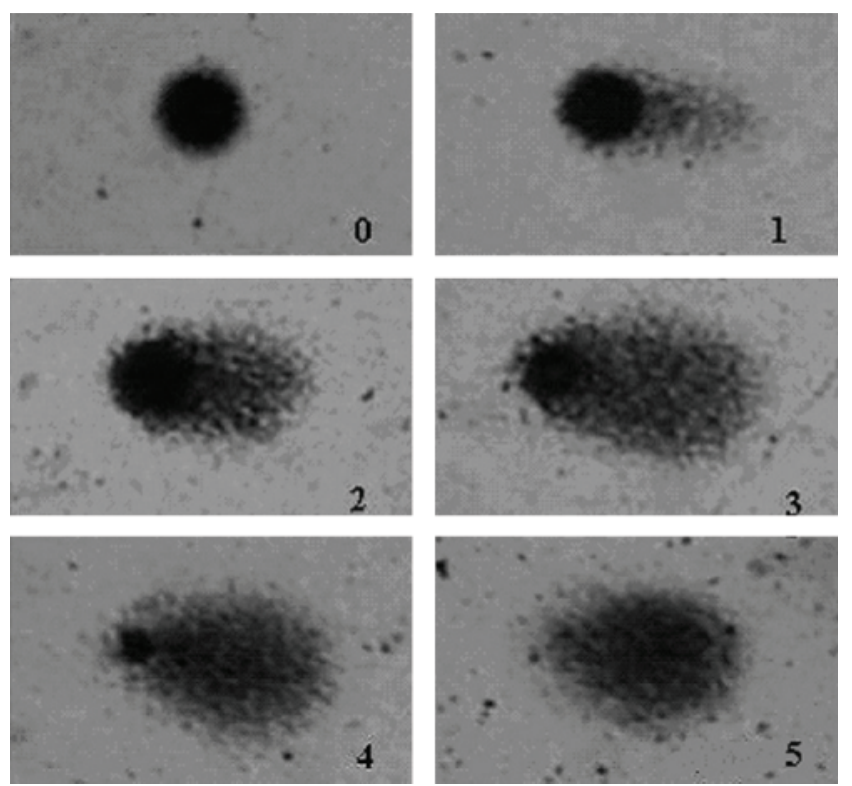

Figure 1: Damage levels considered for analysis in Comet Assay. Level 5 was excluded from our evaluation.

expressed as mean \pm SEM for four independent replicates. The difference was considered significant when $P<0.05$.

\section{Results and Discussion}

Organoselenium compounds, such as ebselen and $(\mathrm{PhSe})_{2}$, are known as pharmacologically active compounds, exhibiting antioxidant, anti-inflammatory, neuroprotective, and antimutagenic properties $[9,20,22,30,31]$. At low concentrations, these compounds protect cells against the insults generated by ROS production, depleting $\mathrm{H}_{2} \mathrm{O}_{2}$ via their GPxmimic activity [32]. In fact, ebselen was used in clinical trials with borderline efficacy [19]. Therefore, the interest in the use of organochalcogens as therapeutic agents has increased in the last years.

Despite their pharmacological properties, organochalcogens can be hepato-, reno-, and neurotoxic to mammals when administered at high doses [33-36]. Accordingly, $(\mathrm{PhSe})_{2}$ administration caused genotoxicity and prooxidant effects in mice $[37,38]$. These toxic effects of ebselen, $(\mathrm{PhSe})_{2}$, and $(\mathrm{PhTe})_{2}$ can be secondary to thiol oxidation of critical target proteins, for instance, lactate dehydrogenase [39], $\mathrm{Na}^{+} / \mathrm{K}^{+}$ ATPase $[9,40]$, and $\delta$-aminolevulinic acid dehydratase $(\delta$ ALAD) [24, 41, 42]. Recently, we have demonstrated that $(\mathrm{PhTe})_{2}$ can also inhibit important antioxidant selenoenzymes [27].

The data available in the literature about organochalcogens toxicity are scarce, mainly in human cells. So, this study examined comparatively the potential cytotoxic and genotoxic effects of ebselen, $(\mathrm{PhSe})_{2}$, and $(\mathrm{PhTe})_{2}$ in human leucocytes.

DMSO did not modify cell viability. At $50 \mu \mathrm{M}$, ebselen, $(\mathrm{PhSe})_{2}$, and $(\mathrm{PhTe})_{2}$ caused a significant decrease in cell viability when compared to the control groups. However, the

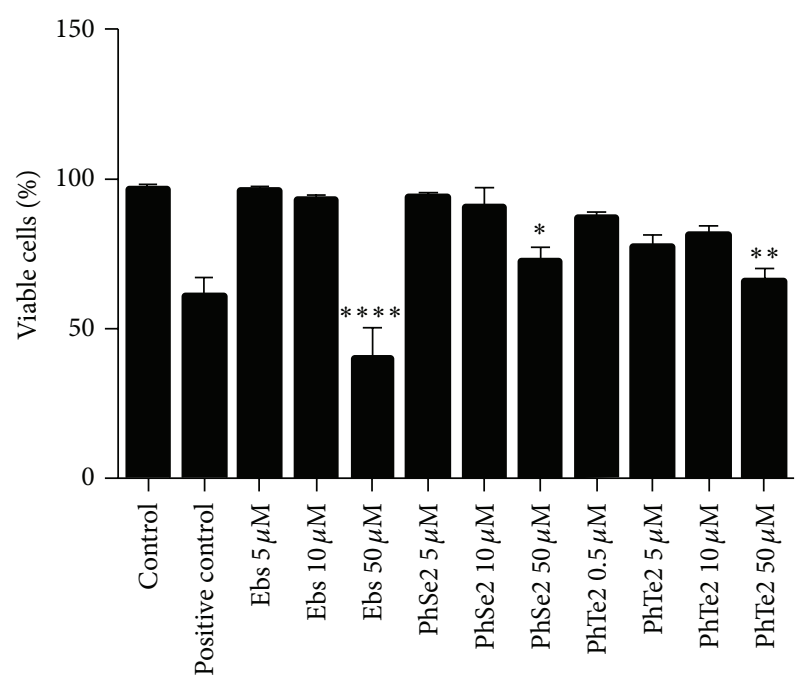

FIgURE 2: Cellular viability of human leucocytes exposed to organochalcogens for 3 hours. The results are expressed as mean \pm SEM from four replicates. One-way ANOVA followed by NewmanKeuls $\left({ }^{*} P<0.05,{ }^{* *} P<0.01\right.$, and $\left.{ }^{* * * *} P<0.0001\right)$.

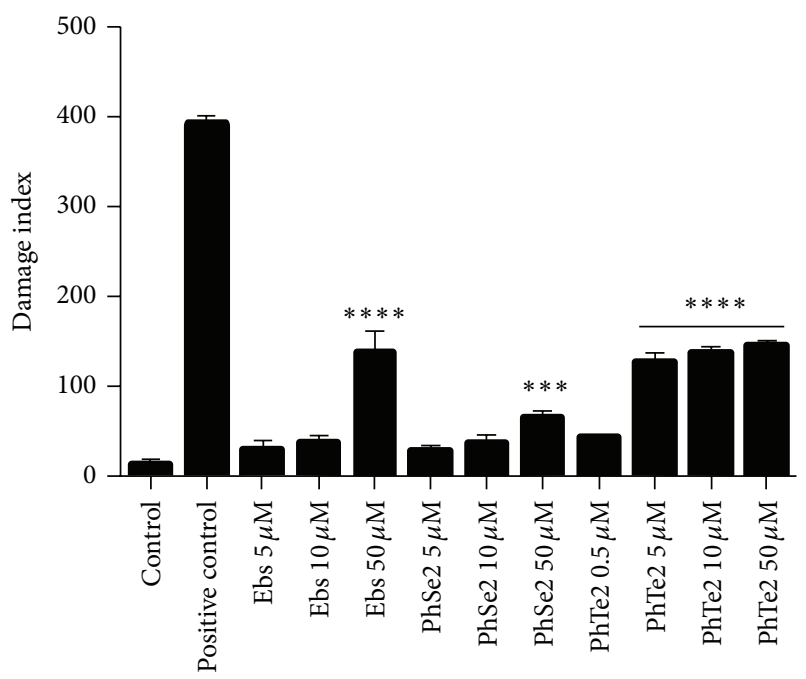

FIGURE 3: DI of human leucocytes exposed to organochalcogen for 3 hours. Data are expressed as mean \pm SEM of four independent experiments done in duplicate. One-way ANOVA followed by Newman-Keuls ( ${ }^{* * *} P<0.001$ and $\left.{ }^{* * * *} P<0.0001\right)$.

effect of ebselen (a decrease of about 60\%) was higher than that of $(\mathrm{PhSe})_{2}$ (a decrease of about $\left.20 \%\right)$ and that of $(\mathrm{PhTe})_{2}$ (a decrease of about $25 \%$ in leucocyte viability, Figure 2). At lower concentrations, ebselen, $(\mathrm{PhSe})_{2}$, and $(\mathrm{PhTe})_{2}$ did not cause significant decrease in cell viability (Figure 2).

DMSO did not modify damage index (DI) of DNA in human blood leucocytes. Ebselen and $(\mathrm{PhSe})_{2}$ at $50 \mu \mathrm{M}$ and $(\mathrm{PhTe})_{2}$ at 5,10 and $50 \mu \mathrm{M}$ caused a significant increase in DI when compared to the control group (Figure 3). Statistical analysis indicated that the effect of $50 \mu \mathrm{M}$ ebselen and $(\mathrm{PhTe})_{2}$ on DI was higher than that caused by $(\mathrm{PhSe})_{2}$ (Figure 3). 
At 5 and $10 \mu \mathrm{M},(\mathrm{PhTe})_{2}$ increased DI, whereas ebselen and $(\mathrm{PhSe})_{2}$ did not cause DNA damage at these concentrations.

Thus, regardless of their structural differences, the toxicity of these compounds can have a common molecular mechanism, that is, oxidation of thiol groups in critical proteins $[22,42,43]$. However, here we observed that ebselen exhibited higher cytotoxicity in human leucocytes than $(\mathrm{PhSe})_{2}$ and $(\mathrm{PhTe})_{2}$. The higher toxicity of ebselen may be related to its capacity to induce thiol oxidation on lactate dehydrogenase [39] and mitochondrial complexes I and II [44] more than $(\mathrm{PhSe})_{2}$ and $(\mathrm{PhTe})_{2}$, which can cause the impairment of cell respiration and, consequently, cell death. Additionally, we observed that ebselen was more genotoxic than $(\mathrm{PhSe})_{2}$, and $(\mathrm{PhTe})_{2}$ was the most genotoxic of the three compounds. A report in the literature shows that $(\mathrm{PhTe})_{2}$ induces cell death via oncosis [45], which is a different type of cell death than that induced by ebselen $[9,46]$ and $(\mathrm{PhSe})_{2}$ [47]. The different genotoxicity potential may be related to differences in the interaction of these compounds with the reparing DNA machinery, in addition to differences in the reactivity with critical thiol-containing proteins.

\section{Conclusion}

In summary, this study shows that ebselen, $(\mathrm{PhSe})_{2}$, and $(\mathrm{PhTe})_{2}$ can cause cytotoxicity and genotoxicity in human leucocytes, that was expressed, respectively, by a decrease in cell viability in Trypan's Blue exclusion test and an increase of DI in Comet Assay, where the cytotoxic effect of ebselen was more pronounced, while $(\mathrm{PhTe})_{2}$ presented the highest genotoxic effect in freshly isolated human leucocytes. Here, the acute cytotoxicity did not correspond with in vivo toxicity of the compounds [9], probably because (PhTe) ${ }_{2}$ induces cell death by a different way than that induced by ebselen and $(\mathrm{PhSe})_{2}$, or otherwise they can have some common steps (for instance, oxidation of thiol proteins, but with different potency and perhaps with some different targets). However, the genotoxicity was in the same order of the in vivo toxicity to mice (i.e., $(\mathrm{PhTe})_{2}>$ ebselen $\left.>(\mathrm{PhSe})_{2}\right)$ [9], confirming that the use of Comet Assay in human leucocytes is a good strategy for a preliminary study of genotoxicity. These results indicate that in vitro genotoxicity in white blood cells should be considered as an early step in the investigation of potential toxicity of organochalcogens before performing in vivo studies with vertebrates. However, more studies are needed to elucidate the toxic effects of ebselen, $(\mathrm{PhSe})_{2}$ and $(\mathrm{PhTe})_{2}$, and their mechanisms of action in different cell types.

\section{Conflict of Interests}

The authors declare that there is no conflict of interests regarding the publication of this paper.

\section{Acknowledgments}

This paper is under the financial support of CNPq, CAPES, and FAPERGS.

\section{References}

[1] G. F. Combs Jr. and S. B. Combs, "The nutritional biochemistry of selenium," Annual Review of Nutrition, vol. 4, pp. 257-280, 1984.

[2] D. H. Holben and A. M. Smith, "The diverse role of selenium within selenoproteins: a review," Journal of the American Dietetic Association, vol. 99, no. 7, pp. 836-843, 1999.

[3] L. V. Papp, J. Lu, A. Holmgren, and K. K. Khanna, "From selenium to selenoproteins: synthesis, identity, and their role in human health," Antioxidants and Redox Signaling, vol. 9, no. 7, pp. 775-806, 2007.

[4] L. Zhong, E. S. J. Arnér, and A. Holmgren, "Structure and mechanism of mammalian thioredoxin reductase: the active site is a redox-active selenolthiol/selenenylsulfide formed from the conserved cysteine-selenocysteine sequence," Proceedings of the National Academy of Sciences of the United States of America, vol. 97, no. 11, pp. 5854-5859, 2000.

[5] K. El-Bayoumy, "The protective role of selenium on genetic damage and on cancer," Mutation Research, vol. 475, no. 1-2, pp. 123-139, 2001.

[6] G. Alfthan, A. Aro, H. Arvilommi, and J. K. Huttunen, "Selenium metabolism and platelet glutathione peroxidase activity in healthy Finnish men: effects of selenium yeast, selenite, and selenate," American Journal of Clinical Nutrition, vol. 53, no. 1, pp. 120-125, 1991.

[7] G. P. Bienert, M. D. Schüssler, and T. P. Jahn, "Metalloids: essential, beneficial or toxic? Major intrinsic proteins sort it out," Trends in Biochemical Sciences, vol. 33, no. 1, pp. 20-26, 2008.

[8] A. Taylor, "Biochemistry of tellurium," Biological Trace Element Research, vol. 55, no. 3, pp. 231-239, 1996.

[9] C. W. Nogueira, G. Zeni, and J. B. T. Rocha, "Organoselenium and organotellurium compounds: toxicology and pharmacology," Chemical Reviews, vol. 104, no. 12, pp. 6255-6285, 2004.

[10] D. S. Avila, A. Benedetto, C. Au et al., "Organotellurium and organoselenium compounds attenuate $\mathrm{Mn}$-induced toxicity in Caenorhabditis elegans by preventing oxidative stress," Free Radical Biology and Medicine, vol. 52, no. 9, pp. 1903-1910, 2012.

[11] A. L. Braga, E. E. Alberto, L. C. Soares, J. B. T. Rocha, J. H. Sudati, and D. H. Roos, "Synthesis of telluroamino acid derivatives with remarkable GPx like activity," Organic and Biomolecular Chemistry, vol. 7, no. 1, pp. 43-45, 2009.

[12] C.-M. Andersson, R. Brattsand, A. Hallberg et al., "Diaryl tellurides as inhibitors of lipid peroxidation in biological and chemical systems," Free Radical Research, vol. 20, no. 6, pp. 401410, 1994 .

[13] J. Kanski, J. Drake, M. Aksenova, L. Engman, and D. A. Butterfield, "Antioxidant activity of the organotellurium compound 3-[4-(N,N-dimethylamino)benzenetellurenyl]propanesulfonic acid against oxidative stress in synaptosomal membrane systems and neuronal cultures," Brain Research, vol. 911, no. 1, pp. 12-21, 2001.

[14] C. Jacob, G. E. Arteel, T. Kanda, L. Engman, and H. Sies, "Water-soluble organotellurium compounds: catalytic protection against peroxynitrite and release of zinc from metallothionein," Chemical Research in Toxicology, vol. 13, no. 1, pp. 3-9, 2000.

[15] A. S. De Freitas and J. B. T. Rocha, "Diphenyl diselenide and analogs are substrates of cerebral rat thioredoxin reductase: a pathway for their neuroprotective effects," Neuroscience Letters, vol. 503, no. 1, pp. 1-5, 2011. 
[16] G. Mugesh, A. Panda, H. B. Singh, N. S. Punekar, and R. J. Butcher, "Glutathione peroxidase-like antioxidant activity of diaryl diselenides: a mechanistic study," Journal of the American Chemical Society, vol. 123, no. 5, pp. 839-850, 2001.

[17] H. Sies, "Ebselen, a selenoorganic compound as glutathione peroxidase mimic," Free Radical Biology and Medicine, vol. 14, no. 3, pp. 313-323, 1993.

[18] R. Zhao and A. Holmgren, "A novel antioxidant mechanism of ebselen involving ebselen diselenide, a substrate of mammalian thioredoxin and thioredoxin reductase," The Journal of Biological Chemistry, vol. 277, no. 42, pp. 39456-39462, 2002.

[19] T. Yamaguchi, K. Sano, K. Takakura et al., "Ebselen in acute ischemic stroke: a placebo-controlled, double-blind clinical trial," Stroke, vol. 29, no. 1, pp. 12-17, 1998.

[20] J. I. Rossato, L. A. Ketzer, F. B. Centurião et al., "Antioxidant properties of new chalcogenides against lipid peroxidation in rat brain," Neurochemical Research, vol. 27, no. 4, pp. 297-303, 2002.

[21] C. Sanmartín, D. Plano, and J. A. Palop, "Selenium compounds and apoptotic modulation: a new perspective in cancer therapy," Mini-Reviews in Medicinal Chemistry, vol. 8, no. 10, pp. 10201031, 2008.

[22] C. W. Nogueira and J. B. T. Rocha, "Toxicology and pharmacology of selenium: emphasis on synthetic organoselenium compounds," Archives of Toxicology, vol. 85, no. 11, pp. 1313-1359, 2011.

[23] C. Ip, H. J. Thompson, Z. Zhu, and H. E. Ganther, "In vitro and in vivo studies of methylseleninic acid: evidence that a monomethylated selenium metabolite is critical for cancer chemoprevention," Cancer Research, vol. 60, no. 11, pp. 28822886, 2000.

[24] N. B. V. Barbosa, J. B. T. Rocha, G. Zeni, T. Emanuelli, M. C. Beque, and A. L. Braga, "Effect of organic forms of selenium on $\delta$-aminolevulinate dehydratase from liver, kidney, and brain of adult rats," Toxicology and Applied Pharmacology, vol. 149, no. 2, pp. 243-253, 1998.

[25] R. M. Rosa, D. J. Moura, A. C. Romano e Silva, J. Saffi, and J. A. Pêgas Henriques, "Antioxidant activity of diphenyl diselenide prevents the genotoxicity of several mutagens in Chinese hamster V79 cells," Mutation Research, vol. 631, no. 1, pp. 44-54, 2007.

[26] P. Santofimia-Castaño, G. M. Salido, and A. Gonzáles, "Ebselen alters mitochondrial physiology and reduces viability of rat hippocampal astrocytes," DNA and Cell Biology, vol. 32, no. 4, pp. 147-155, 2013.

[27] B. Comparsi, D. F. Meinerz, J. L. Franco et al., "Diphenyl ditelluride targets brain selenoproteins in vivo: inhibition of cerebral thioredoxin reductase and glutathione peroxidase in mice after acute exposure," Molecular and Cellular Biochemistry, vol. 370, pp. 173-182, 2012.

[28] B. B. Mischell and S. M. Shiingi, Selected Methods in Cellular Immunology, W.H. Freeman, 1980.

[29] A. R. Collins, "The comet assay for DNA damage and repair: principles, applications, and limitations," Molecular Biotechnology, vol. 26, no. 3, pp. 249-261, 2004.

[30] M. Farina, M. E. S. Frizzo, F. A. A. Soares et al., "Ebselen protects against methylmercury-induced inhibition of glutamate uptake by cortical slices from adult mice," Toxicology Letters, vol. 144, no. 3, pp. 351-357, 2003.

[31] A. S. de Freitas, V. R. Funck, M. D. S. Rotta et al., "Diphenyl diselenide, a simple organoselenium compound, decreases methylmercury-induced cerebral, hepatic and renal oxidative stress and mercury deposition in adult mice," Brain Research Bulletin, vol. 79, no. 1, pp. 77-84, 2009.

[32] G. Mugesh and H. B. Singh, "Synthetic organoselenium compounds as antioxidants: glutathione peroxidase activity," Chemical Society Reviews, vol. 29, no. 5, pp. 347-357, 2000.

[33] E. N. Maciel, E. M. M. Flores, J. B. T. Rocha, and V. Folmer, "Comparative deposition of diphenyl diselenide in liver, kidney, and brain of mice," Bulletin of Environmental Contamination and Toxicology, vol. 70, no. 3, pp. 470-476, 2003.

[34] F. C. Meotti, V. C. Borges, G. Zeni, J. B. T. Rocha, and C. W. Nogueira, "Potential renal and hepatic toxicity of diphenyl diselenide, diphenyl ditelluride and Ebselen for rats and mice," Toxicology Letters, vol. 143, no. 1, pp. 9-16, 2003.

[35] M. Farina, F. A. A. Soares, G. Zeni, D. O. Souza, and J. B. T. Rocha, "Additive pro-oxidative effects of methylmercury and ebselen in liver from suckling rat pups," Toxicology Letters, vol. 146, no. 3, pp. 227-235, 2004.

[36] M. R. Straliotto, G. Mancini, J. De Oliveira et al., "Acute exposure of rabbits to diphenyl diselenide: a toxicological evaluation," Journal of Applied Toxicology, vol. 30, no. 8, pp. 761768, 2010.

[37] R. M. Rosa, N. C. Hoch, G. V. Furtado, J. Saffi, and J. A. P. Henriques, "DNA damage in tissues and organs of mice treated with diphenyl diselenide," Mutation Research, vol. 633, no. 1, pp. 35-45, 2007.

[38] T. H. Degrandi, I. M. De Oliveira, G. S. D’Almeida et al., "Evaluation of the cytotoxicity, genotoxicity and mutagenicity of diphenyl ditelluride in several biological models," Mutagenesis, vol. 25, no. 3, pp. 257-269, 2010.

[39] T. H. Lugokenski, L. G. Mller, P. S. Taube, J. B. T. Rocha, and M. E. Pereira, "Inhibitory effect of ebselen on lactate dehydrogenase activity from mammals: a comparative study with diphenyl diselenide and diphenyl ditelluride," Drug and Chemical Toxicology, vol. 34, no. 1, pp. 66-76, 2011.

[40] V. C. Borges, J. B. T. Rocha, and C. W. Nogueira, "Effect of diphenyl diselenide, diphenyl ditelluride and ebselen on cerebral $\mathrm{Na}^{+}, \mathrm{K}^{+}$-ATPase activity in rats," Toxicology, vol. 215, no. 3, pp. 191-197, 2005.

[41] R. A. Saraiva, D. C. Bueno, P. A. Nogara, and J. B. T. Rocha, "Molecular docking studies of disubstituted diaryl diselenides as mammalian $\delta$-aminolevulinic acid dehydratase enzyme inhibitors," Journal of Toxicology and Environmental Health A, vol. 75, no. 16-17, pp. 1012-1022, 2012.

[42] J. B. T. Rocha, R. A. Saraiva, S. C. Garcia, F. S. Gravina, and C. W. Nogueira, "Aminolevulinate dehydratase $(\delta$-ALA-D) as marker protein of intoxication with metals and other prooxidant situations," Toxicology Research, vol. 1, no. 2, pp. 85-102, 2012.

[43] C. F. Yang, H. M. Shen, and C. N. Ong, "Intracellular thiol depletion causes mitochondrial permeability transition in ebseleninduced apoptosis," Archives of Biochemistry and Biophysics, vol. 380, no. 2, pp. 319-330, 2000.

[44] R. L. Puntel, D. H. Roos, R. L. Seeger, and J. B. T. Rocha, "Mitochondrial transfer chain complexes inhibition by different organochalcogens," Toxicology in Vitro, vol. 27, pp. 59-70, 2013.

[45] S. Roy and D. Hardej, "Tellurium tetrachloride and diphenyl ditelluride cause cytotoxicity in rat hippocampal astrocytes," Food and Chemical Toxicology, vol. 49, no. 10, pp. 2564-2574, 2011.

[46] C.-F. Yang, H.-M. Shen, and C.-N. Ong, "Ebselen induces apoptosis in HepG2 cells through rapid depletion of intracellular 
thiols," Archives of Biochemistry and Biophysics, vol. 374, no. 2, pp. 142-152, 2000.

[47] T. Posser, M. T. De Paula, J. L. Franco, R. B. Leal, and J. B. T. Da Rocha, "Diphenyl diselenide induces apoptotic cell death and modulates ERK1/2 phosphorylation in human neuroblastoma SH-SY5Y cells," Archives of Toxicology, vol. 85, no. 6, pp. 645651, 2011. 

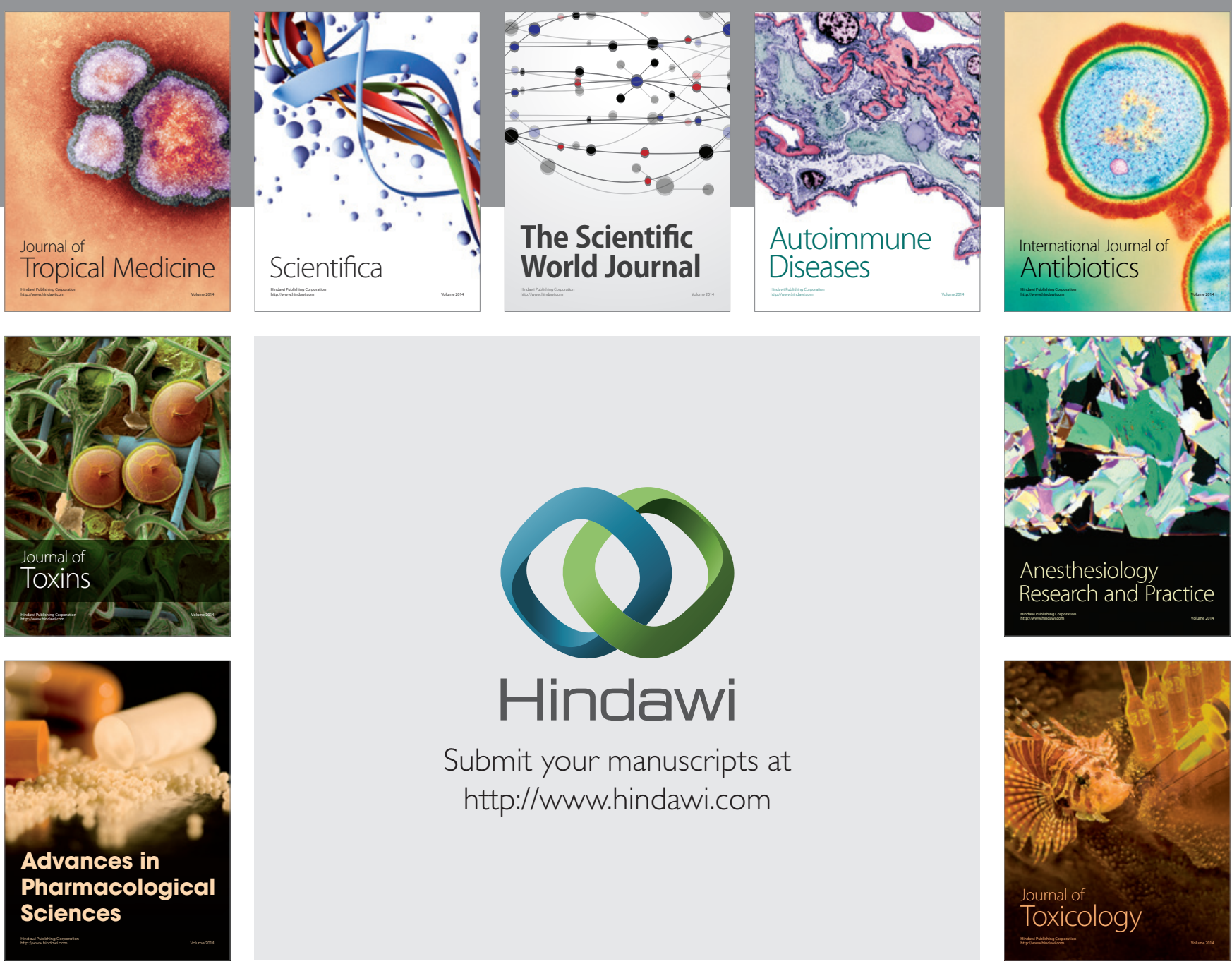

\section{Hindawi}

Submit your manuscripts at

http://www.hindawi.com
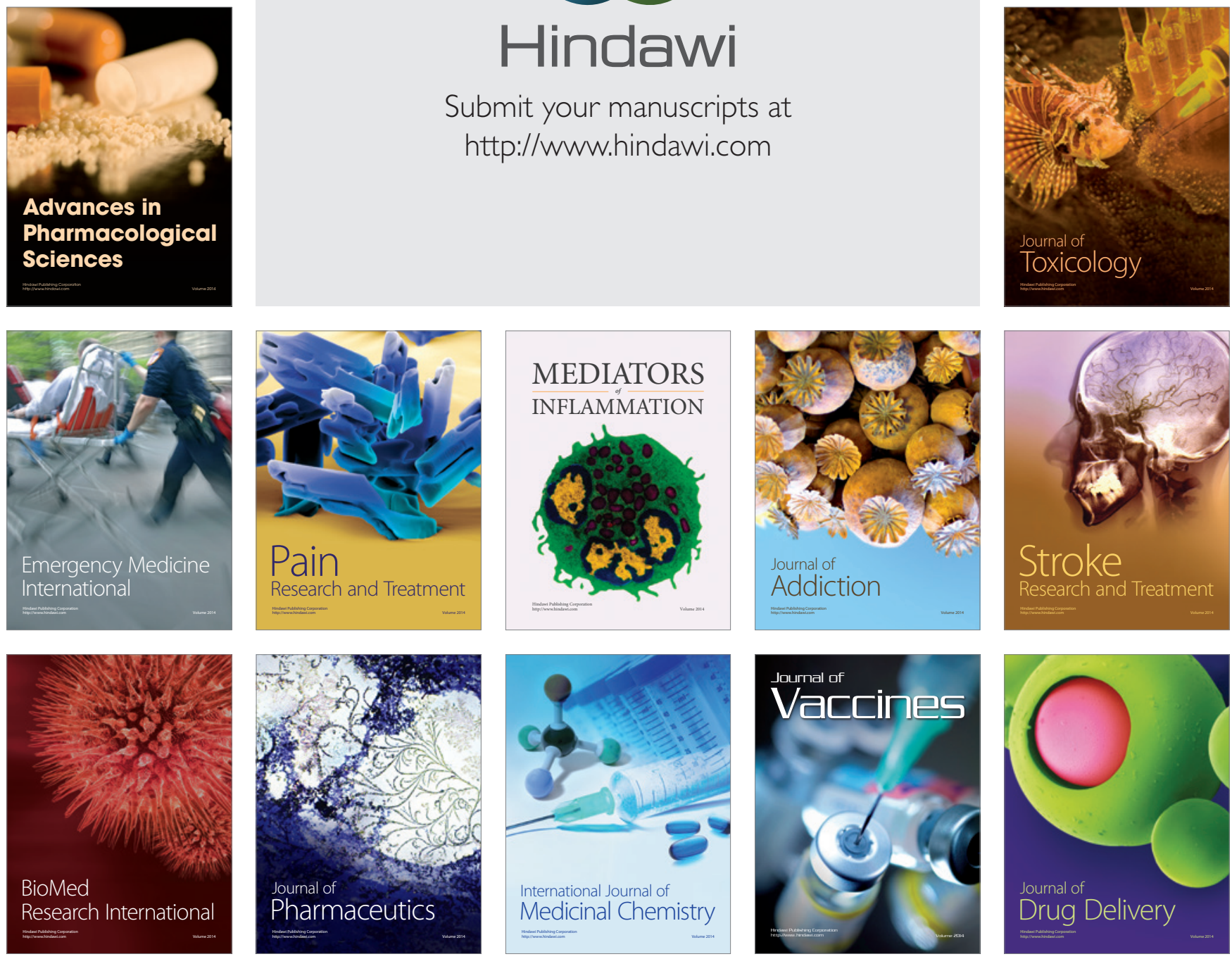